\title{
HEAT STRESS IN POULTRY. II. METHODS AND TECHNIQUES FOR PREVENTION AND ALLEVIATION*
} (review)

\section{V.I. FISININ, A.Sh. KAVTARASHVILI}

All-Russian Research and Technological Poultry Institute, Federal Agency of Scientific Organizations, 10, ul. Ptitsegradskaya, Sergiev Posad-11, Moscow Province, 141300 Russia, e-mail fisinin@vnitip.ru, alexk@vnitip.ru Received March 23, 2015

\section{Abstract}

An adverse effect of heat stress in poultry depends on both the external factors such as diet, water supply, rearing technology, birds' population density, air humidity and flow rate, etc., and the internal factors, particularly, poultry species and breed specificity, physiological conditions, etc. Herein, the approaches to prevention and alleviation of heat stress in poultry are summarized and discussed. Different strategies were proposed for lowering of body heat production and for better heat dissipation, thus maintaining productivity and product quality and minimizing losses for poultry farms. These strategies include the increase in energetic level of a diet in accordance with decrease in feed consumption due to stress (N.J. Daghir, 2009) and inclusion of higher (up to 4-5 \%) levels of fat (B.L. Red, 1981; N. Usayran et al., 2001; A.A. Ghazalah et al., 2008); decrease by $2-4 \%$ of dietary crude protein (Q.U. Zaman et al., 2008) and carbohydrate levels (metabolization of fat produces less heat than protein and carbohydrates) (N.A. Musharaf, J.D. Latshaw, 1999; N.J. Daghir, 2008); changes in amino acid profile of a diet (diets imbalanced in amino acids may increase heat production; moreover, requirements in lysine and sulfur-containing amino acids are much higher in heat stressed poultry) (R.M. Gous, T.R. Morris, 2005; S. Syafwan et al., 2011; O. Vjreck, M. Kirchgessner, 1980); supplementation with additional $250 \mathrm{ppm}$ of vitamin C (M. Ciftci et al., 2005; A. Kavtarashvili, T. Kolokolnikova, 2010), 200 ppm of vitamin E (Z.Y. Niu et al., 2009; A.A. Rashidi et al., 2010), 8000 IU/kg of vitamin A (H. Lin et al., 2002), minerals or proper premix of vitamins and minerals (V.I. Fisinin et al., 2009), supplementation of feed or drinking water with electrolytes $\mathrm{NaHCO}_{3}, \mathrm{KCl}, \mathrm{CaCl}_{2}, \mathrm{NH}_{4} \mathrm{Cl}$ (R.G. Teeter et al., 1985; T. Ahmad et al., 2005); pelleting of diets (R.M. Gous, T.R. Morris, 2005; A. Kavtarashvili, T. Kolokolnikova, 2010); special regimes of feeding (K. Hiramoto et al., 1995; M.H. Uzum, H.D. Oral Toplu, 2013) and intermitted lighting (A. Kavtarashvili, T. Kolokolnikova, 2010; D. Balnave, S.K. Muheereza, 1998); periodic (in 7-day periods) substitution of soda $\left(\mathrm{NaHCO}_{3}\right)$ for 50-80 \% of dietary salt (P.S. Silva et al., 1996; A. Kavtarashvili et al., 2010); feeding of mixture of ground mussel and lime (1:1) from separate feeders with simultaneous decrease in dietary Ca level; inclusion of dietary enzyme preparations (V.I. Fisinin et al., 1999) and probiotic strains of Lactobacillus (P.T. Lan et al., 2004); the use of special anti-stress additives and preparations (P. Surai et al., 2012; P. Surai et al., 2013); moistening of enzyme-supplemented diets (H. Lin et al., 2006; M.A. Khoa, 2007); increase in air velocity in poultry houses up to $2.0-2.5 \mathrm{~m} / \mathrm{s}$ (J. Donald, 2000); tunnel ventilation systems (M. Czarick, B.L. Tyson, 1989); systems of evaporative air cooling (J. Donald, 2000; E.S. Mailyan, 2007); the use of heat-insulating and light-reflective roof materials, sprinkling of roof with cold water (S. Yahav et al., 2004); 15-20\% decrease in stock density (T. Ahmad et al., 2006); a decreased litter thickness (to 3-5 cm) (Salah H.M. Esmail, 2001); decrease in any disturbing activity (vaccination, repopulation etc.) during the hottest hours; providing poultry with constant access to water including days when poultry is vaccinated via water; elimination of spray vaccines during heat stress (O. Mikhailovskaya et al., 2010); regular cleaning and disinfection of drinking water and drinking systems; acidification of drinking water (A. Kavtarashvili, 2013); regular refilling of drinking system with fresh and cold water; isolation and shading of water tanks and pipes exposed to direct sunlight; cooling of drinking water (S. Yahav et al., 1996); thermal training of embryos during $2^{\text {nd }}$ half of embryogenesis (Y. Piestun et al., 2008) and 3-day chicks (S. Yahav et al., 2001; S. Yahav et al. 2004); genetic improvements in thermal tolerance (A.V. Miftahutdinov, 2011) including activated expression of naked neck gene $N a$ and frizzle feather gene $F$ (N. Deeb et al., 2001; M.V. Raju et al., 2004). and alleviation.

Keywords: temperature, heat stress, poultry farming, productivity, methods of prevention

* «Heat stress in poultry. I. Danger, related physiological changes and symptoms (review)» see in Agricultural Biology, 2015, vol. 50, № 2, pp. 162-171 (doi: 10.15389/agrobiology.2015.2.162rus, doi: 10.15389/agrobiology.2015.2.162eng). 
Heat stress results in behavioral, physiological, and immunological changes in poultry, which has a negative impact on its health, feed consumption, productivity, and quality of products $[1,2]$. This inevitably results in significant financial losses. The severity of the adverse effect of heat stress in poultry depends on external (diet, water supply, rearing technology, birds' population density, air humidity, airflow rate, etc.) and internal (poultry species and breed specificity, physiological condition, etc.) factors [3].

Currently, various methods and techniques for the prevention and alleviation of heat stress in poultry are known.

Feeding methods for dealing with heat stress. Under the high temperature conditions, feed intake is reduced [2], the acid-base balance in the body changes [4, 5], the secretion and activity of endogenous enzymes decreases [6], the intestine absorbing capacity is broken [7], the passage of feed through the gastrointestinal tract is accelerated due to the 3-5 times increased water intake $[8,9]$. As a result, a deficiency of nutrients, vitamins (especially $\mathrm{C}$ and $\mathrm{E}$ ), and some macro- and trace elements arises in the bird's body [10, 11].

To reduce the negative impact of heat stress, researchers suggest various strategies for feeding in poultry.

It is believed that the daily rate of nutrients under conditions of heat stress should be maintained by increasing the density of fodder proportional to the reduction of its consumption $[12,13]$. For example, if the expected reduction in feed consumption is $10 \%$, the content of all nutrients (including vitamins, mineral compounds, and trace elements) must be increased by $10 \%$. But the use of this strategy for certain substances is sometimes limited with the production capability. Thus, the addition of more than 6-8 \% fat to the feed mixture is not always acceptable. In addition, the doses of certain feed additives cannot be changed without knowing how it can affect the health of poultry. In many cases, the reduction in food intake is so great that it cannot be compensated by increasing the amount of nutrients.

Some authors claim that under heat stress, the increase in the proportion of crude protein in the diet at the background of low feed intake plays a positive role $[14,15]$. Other researchers report the dangers of feeding broilers with the feed high protein content at high ambient temperature [16-18]. According to Q.U. Zaman et al. [19], in the heat stress conditions $\left(32-39{ }^{\circ} \mathrm{C}\right)$, the diet with low crude protein $(190 \mathrm{~g} / \mathrm{kg})$ and high content of metabolizable energy $(12.55$ $\mathrm{MJ} / \mathrm{kg}$ ) with standard values of essential amino acids contributes to greater efficiency of broiler chicks than the feed with high amounts of protein $(210 \mathrm{~g} / \mathrm{kg}$ and $230 \mathrm{~g} / \mathrm{kg}$ ) and metabolizable energy $(12.55 \mathrm{MJ} / \mathrm{kg})$.

The inclusion of $5 \%$ of fat [20] in the diet of broiler chicks, $5 \%$ of fat [21] and $4 \%$ of soybean [22] or palm oil [23] for young hens at high temperature makes it possible to improve poultry productivity. This is because, first, fat enhances the palatability of fodder and encourages its consumption, and second, less endogenous heat is produced in fat metabolism than in protein and carbohydrate metabolism [14, 24, 25].

To reduce the endogenous production of heat in poultry under heat stress, V. De Basilio et al. [26] recommend using two diets: during the hottest period of the day it is a diet with higher (by 4-5\%) fat content and lower (by 2$4 \%$ ) amounts of crude protein, in the cooler period it is a diet with a reduced fat content and a higher crude protein proportion.

Positive results are obtained by a change in the proportion of fat and carbohydrates feed energy that is the ratio of effective and metabolizable energy [27]. In practice, the possibility of applying this method is somewhat limited due to the use of feed ingredients that the farms are able to purchase [12]. 
The balance of amino acids is also important. Consuming fodder of an unbalanced amino acid composition, poultry produce more heat per $1 \mathrm{~g}$ of fodder $[11,12]$. The inclusion of additional amino acids in the diet results in the increase of oxidative processes in the follicular tissue, growth and development of follicles, and thus to the increase in poultry productivity [28]. When the ambient temperature increases, the consumption of lysine to maintain $1 \mathrm{~kg}$ of live weight of chickens and sulfur amino acids for the maintenance of egg production grows significantly [29]. Many authors [30, 31] find that fodder unbalanced in its amino acid composition increases the content of nitrogen compounds in the litter, which leads to the accumulation of ammonia in the poultry house and negatively affects the productivity, health, and thermoregulation in poultry.

Positive results were obtained with supplementation of fodder with additional $250 \mathrm{mg} / \mathrm{kg}$ of vitamin $\mathrm{C}[32,33]$. At higher doses $(500 \mathrm{mg} / \mathrm{kg}$ and $750 \mathrm{mg} / \mathrm{kg}$ of feed) the effect was negative [34]. When ascorbic acid is added to water, not to the fodder, water intake increases [35].

Z.Y. Niu et al. [36] found that under heat stress $\left(38{ }^{\circ} \mathrm{C}\right)$ broilers treated with vitamin $\mathrm{E}(200 \mathrm{mg} / \mathrm{kg}$ of feed $)$ had higher macrophage activity and increased levels of $\operatorname{IgM}$ and $\mathrm{IgG}$ compared to the poultry that were not given the vitamin. There is evidence [37] of a significant intensification of phagocytosis, an increase in the number of T-lymphocytes and SRBC (sheep red blood cells) antibodies, spleen weight, and bursa of Fabricius in broiler chickens in cases of supplementation of fodder with vitamin $\mathrm{E}(100 \mathrm{IU} / \mathrm{kg}$ feed) during heat stress $\left(32{ }^{\circ} \mathrm{C}\right)$. Other researchers [38] noted that at $33{ }^{\circ} \mathrm{C}$ a supplement of vitamin $\mathrm{E}$ in a dose of $200 \mathrm{mg} / \mathrm{kg}$ of fodder increased SRBC antibody titers in egg-production chickens. Vitamin $\mathrm{E}$ is an essential component of antioxidant protection, but recent studies have shown that it is not always able to improve the situation [39, 40].

The harmful effects of heat stress on egg laying can also be avoided by supplementation of fodder with vitamin A (8,000 IU/kg of feed) [41]. The greatest effect is achieved when complexes of vitamins, for example $\mathrm{C}$ and $\mathrm{E}$ [42], $\mathrm{A}$ and $\mathrm{E}$ [43], or the relevant vitamin-mineral premixes are fed [40].

High efficiency was shown for fodder or water supplements of various salts electrolytes $\left(\mathrm{NaHCO}_{3}, \mathrm{KCl}, \mathrm{CaCl}_{2}, \mathrm{NH}_{4} \mathrm{Cl}\right)$ [4, 44]. Supplementing feed with sodium bicarbonate at the rate of $4-10 \mathrm{~kg} / \mathrm{t}$ helps restore the acid-base balance lost in alkalosis resulting from hyperpnoea in birds in the heat. An additional amount of electrolytes such as potassium chloride $(0.25-0.5 \%$ in drinking water or $0.5-1.0 \%$ in feed) restores the electrolyte balance [33]. Drinking electrolyte solutions should be given in the morning before the rapid rise of air temperature [45]. Excessive potassium is better endured by birds than excessive sodium [46]. Under heat stress, the body tends to retain more electrolytes ( $\mathrm{Na}, \mathrm{K}$, $\mathrm{Cl})$ to maintain the acid-base balance. The amount of electrolytes in the urine is dependent on their content in the feed and on the ambient temperature. Water consumption is associated with the poultry age, with the $\mathrm{K}, \mathrm{Na}$, and $\mathrm{Cl}$ uptake with feed and has a direct effect on the litter moisture content and changes in rectal temperature $[47,48]$.

Fodder structure may affect the amount of energy spent for its consumption. For example, the intake of pelleted feed requires one-third less time compared with the same amount of spilled feed and allows birds to save about $6 \%$ of energy [12], which can be beneficial for reducing heat production. Furthermore, pelleting increases the physical density of feed providing greater intake of nutrients [12, 33, 49].

Special feeding regimes provide positive results. Some scientists [50-52] recommend limiting feeding poultry 4-6 hours prior to the heat stress. During 
this time, the remains of food are evacuated from the gut, and the increase of heat associated with feed consumption in the hottest period of the day is reduced. It is advisable to move the time of the main feeding to the morning and evening or use the «night feeding principle» [53]. To do this, we recommend implementing modes of intermittent illumination providing night illumination for 2 hours, dark periods of 3-4 hours in the hottest time of the day and night feeding [49, 54]. Other authors propose to add gradually (15 minutes per week) one hour of illumination at night during the hot period of the year (for example, from midnight to 1:00 a.m. but not less than after 4 hours since the end of the main illumination period). The regular illumination regime mode is restored in the fall, gradually reducing the «night feeding» in the same way. However, the use of such technology in poultry may shift the circadian rhythm of egg laying $[55,56]$, which may lead to some reduction in productivity. D. Balnave and S.K. Muheereza [57] reported that under a regime of intermittent illumination of 3L:1D (L means light D means darkness, h) compared with 16L: 8D at high temperature $\left(32^{\circ} \mathrm{C}\right)$, feed intake, body weight, egg weight, thickness, and strength of egg shell increased significantly. The positive effect of intermittent illumination is due to the fact that birds move less in the dark and, thus producing less heat energy. It was found that at high temperature in poultry houses, feed intake can be stimulated by increasing the multiplicity of its distribution up to 5 times or more with periodic idle starts of feeding system lines [49].

The adverse effect of heat stress can be alleviated by replacing the salt in the fodder (50-80\%) with baking soda (periodically for 7 days), in the most severe cases, the amount of soda supplement is allowed to reach $2-4 \mathrm{~kg}$ per 1 ton of fodder mixtures $[53,58]$. There is evidence that supplementing the fodder with chromium at a dose of $600 \mathrm{mg} / \mathrm{kg}$ [59] or chromium $(400 \mathrm{mg} / \mathrm{kg})$ in combination with ascorbic acid $(250 \mathrm{mg} / \mathrm{kg})$ [60] increases the bodyweight of broilers. Positive results are obtained with the feeding of a mixture of ground mussel and lime (1:1) from separate feeders with a simultaneous decrease in dietary Ca level [53, 61].

To improve nutrient digestibility under heat stress, the inclusion of dietary enzyme preparations in the diet is recommended [53, 61]. Enhance feed palatability and nutrient digestibility is also enhanced by feed moistening using exogenous enzymes [49, 62, 63].

Probiotic strains of Lactobacillus can enrich the diversity of flora in the jejunum and cecum of chickens and restore the microbial balance in broiler chicks after heat stress [64]. During heat stress, special feed supplements and drugs may be used - ProviGard, Catosal (Germany), Betfin S1, OptiPro, zinc bacitracin, feed antibiotics, osmo-protective supplements, etc. [3, 40, 65-67].

While the feeding methods recommended to reduce the effects of heat stress have shown their potential benefits, none of them can be considered as the only ideal method or as effective as reducing the heat load on poultry using a variety of technological methods [12].

Reducing air temperature in poultry houses. As it is known, body temperature is determined by heat generation (heat production) and heat dissipation (heat release). At high temperatures, poultry suffer difficulties in achieving a balance between heat production and heat loss. If heat production exceeds the maximum loss for a long time, birds may die. Thus, a temperature increase of $4{ }^{\circ} \mathrm{C}$ causes the death of broilers [13].

To reduce the temperature in poultry houses, an increase in air velocity to $2.0-2.5 \mathrm{~m} / \mathrm{s}$ and in the amount of fresh air to $6-7 \mathrm{~m}^{3}$ per $1 \mathrm{~kg}$ of body weight per hour is recommended, which creates a feeling of coolness in birds [53, 68]. At this, the use of tunnel ventilation maximizes the convective heat loss, espe- 
cially in high humidity conditions [69]. Farms should have spare power supply systems for the event of disruptions in hot periods. It is necessary to equip premises with evaporative cooling systems in which air passes through paper napkins moistened with water and enters the poultry house in cooled condition. With it, even at the ambient temperature above $35-38{ }^{\circ} \mathrm{C}$, a temperature of $24-28{ }^{\circ} \mathrm{C}$ and below can be maintained in poultry houses [68, 70]. But one should keep in mind that the higher the humidity, the less effective evaporative cooling [62].

Misting systems (fine mist generated under high pressure inside the premises) increases the effectiveness of ventilation to $50 \%$, but it is important to remember that poultry tolerates the impact of high temperatures at high relative humidity much worse, so in such conditions, it is not allowed to moisture floor, bathe birds, etc. Humidity in poultry houses at high temperature in the absence of adequate ventilation should not exceed $50 \%[68,71]$.

The effectiveness of heat-insulating and reflective roofing materials (e.g., aluminum-plastic foil), irrigation of roofs with cold water, etc. has been reported $[72,73]$. According to some authors, at high ambient temperatures, it is advisable to reduce the stocking poultry density by $15-20 \%[33,47]$. According to V. Holik (74), the stocking density in the floor and cage poultry at the temperature of $25{ }^{\circ} \mathrm{C}$ should be 5.5 birds per sq. $\mathrm{m}$ and $450 \mathrm{~cm}^{2}$ per bird; at $30{ }^{\circ} \mathrm{C}, 4.5$ birds per sq. $\mathrm{m}$ and $550 \mathrm{~cm}^{2}$ per bird; at $35{ }^{\circ} \mathrm{C}, 3.5$ birds per sq. $\mathrm{m}$ and $650 \mathrm{~cm}^{2}$ per bird. To reduce the release of biological heat of decomposing components, the thickness of the bedding used should be not more than 3-5 cm [70, 75]. The frequency of litter removal from houses should also be increased [70].

Handling birds under heat stress. When handling birds during heat stress, the following rules should be followed [45]: birds should not be disturbed during the hottest period of the day; vaccination, transportation of livestock to poultry houses for adult birds should be performed during the cool time of the day (early morning or late evening); under vaccination via drinking water, water supply should not be interrupted; spray vaccination should be excluded; prevention of bacterial infection should be performed (breathing with open mouth, there is no air filtration through nasal passages, secondary bacterial infections gets in the body, which results in bird wasting).

Features of drinking water preparation and providing water to poultry during periods of high temperature. At high ambient temperatures, favorable conditions for the growth of microorganisms, pathogenic bacteria, fungi, and algae arise in drinking systems due to the presence of mineral and organic impurities in water. They accumulate and form a so-called biofilm. In addition, as a result of mineral substances deposition, a lime peel is formed in pipes that serves as a refuge for micro-organisms and disrupts the normal operation of drinking systems [76].

At high temperatures, it is necessary to clean and disinfect water and drinking systems using products that contain a mixture of various organic (formic, acetic, citric, fumaric, etc.) acids. Acidification of water contributes to the sanitation of oral cavity, nose, and the entire digestive system in poultry, favors beneficial bacteria, and inhibits pathogens (Salmonellae, Escherichia coli, mold and yeast fungi) in the gastrointestinal tract. The acidic environment also helps the production of pancreatic enzymes, enhances the conversion of pepsinogen to pepsin, and inhibits the passage of chyme through the gastrointestinal tract [76]. In addition, it is advisable to ensure systematic draining from drinking systems for filling them with fresh cold water; insulation of water tanks and water pipes located in the sun, their protection by shade; cooling of drinking water to 5$18{ }^{\circ} \mathrm{C}$ (increases feed consumption by $\left.5-11.6 \%\right)(8,77)$; providing unlimited access of birds to water and increasing drinking system by $20-25 \%$; timely re- 
placement of water filters [45]. It was found that cold-water intake $\left(10{ }^{\circ} \mathrm{C}\right)$ helps poultry stand the ambient temperature of $42.2^{\circ} \mathrm{C}$ for $11.5 \mathrm{~h}$ [8].

Heat training. The results of heat stress can be effectively alleviated by heat training. The eggs of the meat chicken Cobb were incubated at standard temperature and humidity regime $\left(37.8^{\circ} \mathrm{C} / 56 \%\right.$, control group) [78]. In the experimental group, the eggs were subjected to training from the $7^{\text {th }}$ to the $16^{\text {th }}$ days of incubation for 12 or 24 hours at the temperature of $39.5^{\circ} \mathrm{C}$ and air humidity of $65 \%$. At the 35-th day of cultivation, chickens of all groups were subjected to a thermal load $\left(35.5^{\circ} \mathrm{C}\right.$ for 5 hours), as a result, higher heat resistance of broiler chickens of experimental groups was shown.

It was also found that heat training of 3-day old chicks $\left(36-37.5{ }^{\circ} \mathrm{C}\right.$ for 24 hours) increased poultry resistance to high temperatures in the later period of growth [56, 79]. Usually, right after the exposure to heat, the growth is slowed down but followed by compensatory growth contributing to the formation of greater body weight in broilers at the end of cultivation compared with poultry not subjected to heat training [79].

This phenomenon can be explained with heat training imprintingin developing embryos and with formation of epigenetic thermal adaptation in them manifested in the increased resistance of poultry to high temperatures [80]. A similar opinion is shared by other authors [81, 82] who have found that if poultry eggs are subjected to temperature stress during incubation, hatched individuals demonstrate changes in thermo sensitivity of hypothalamic neurons throughout their life.

Selection and breeding. Increasing of thermostability in poultry by selection and breeding can be considered a promising area of prevention and alleviation of heat stress effects [83]. However, one should remember that the actual heritability of the sign of poultry resistance to high temperatures is very low [84, 85]. In addition, selection for the increase of thermos-tolerance can cause a reduction in growth potential in a comfortable temperature conditions. Therefore, it is necessary to clarify the relationship and interaction of selection signs used in different temperature environments [86].

Results obtained in the study of the effect of heat load $\left(35^{\circ} \mathrm{C} / 50 \% / 14\right.$ days, temperature/humidity/duration) in 38-week-old chickens of the egg crosses Hy-Line Brown, W36, and W98 prove their different thermos-tolerances [87]. Within the period of the thermal stress factor exposure, the reduction in egg production, feed intake, and egg shell thickness was $31.0 \%, 35.0 \%$, and $0.07 \mathrm{~mm}$, respectively, in the brown cross; $19.7 \%, 29.0 \%$, and $0.04 \mathrm{~mm}$ in the W36 cross; and $13.0 \%, 27.0 \%$, and $0.05 \mathrm{~mm}$ in the W98 cross, and mortality, on the contrary, increased, respectively, by $16.0 \% ; 4.0 \%$, and $8.0 \%$. The consistency of changes in the shell thickness and calcium in the gut was detected: in brown cross individuals the absorption decreased by $52.5 \%$, while in other crosses it decreased by $30 \%$ only. The findings suggest that thermos-tolerance in layers of investigated genotypes varies, and the cross W98 livestock has the highest thermal stability. This provision based on the analysis of productivity values is also confirmed by the data on the known markers of the heat stress condition. Thus, polypnoea intensity in W98 is lower as indicated by the value of blood $\mathrm{pCO}_{2}$ : in W36, it decreased by $24 \%$; in brown cross, by $17 \%$; in W98, by $13 \%$ only.

In a recent study [88], thermo-tolerance was evaluated in five commercial chicken genotypes (Lohmann Brown, Lohmann White, New Hampshire, dwarf White Leghorn, and White Leghorn) who were divided into two subgroups. Chickens of the first subgroup of each genotype were kept at a comfortable temperature for a long time $\left(18-20^{\circ} \mathrm{C}\right)$, chickens of the second group were kept under the heat stress conditions $\left(30-32{ }^{\circ} \mathrm{C}\right)$. Feed intake, body weight, egg production, egg 
weight, shell thickness, and strength in all birds of the first subgroup were higher than in those subjected to hyperthermia. The most stable body weight, egg weight, and feed conversion were observed in New Hampshire chickens, and the intensity of egg production and egg mass rate per 1 bird/day proved to be the most stable in White Leghorn chickens. This study showed that the negative manifestation of heat stress depends on the genotype.

The use of genes that contribute to thermal stability, such as the naked neck gene $(\mathrm{Na})$ and the frizzled feather gene $(F)$, in poultry breeding is noteworthy. The naked neck gene $(\mathrm{Na})$ increases the growth rate of broiler chickens, the production of pectoral muscles, the heat loss through the neck, with decreased fat deposits in the skin and pectoral muscle [89, 90]. In heterozygous $(\mathrm{Na} / \mathrm{na})$ and homozygous $(\mathrm{Na} / \mathrm{Na})$ individuals, featherweight relative to body weight is by $20 \%$ and $40 \%$ lower, respectively, compared to fully feathered birds [91]. The frizzled feather gene $(F)$ makes it possible to reduce bird feather insulation. The favorable effect of $F$ gene on the body weight of broilers at high temperature is lower than the effect of $\mathrm{Na}$ gene. However, there is a positive effect of the simultaneous use of heterozygous genes $(\mathrm{Na} / \mathrm{na} \mathrm{и} \mathrm{F} / \mathrm{f})$ in broiler chickens [92].

Thus, feed intake is reduced and water intake is increased under heat stress resulting in the reduction of poultry productivity. To alleviate the effects of heat stress, appropriate adjustments in the diet should be made, which will help reduce the heat production of the bird body and maintain the required intake of feed nutrients. Physical activity of birds needs to be minimized during the hottest time of the day. Prevention and alleviation of heat stress in poultry require an integrated approach and can include the following: selection for heat tolerance; changes in feeding, watering and lighting regimes; changes in the energyprotein ratio and the balance of amino acids in the diet; use of special feed or water supplements (vitamins, trace elements, anti-stress supplements, enzymes, probiotics); poultry houses redesign; improvement of ventilation and cooling systems; special technological methods. The choice of appropriate measures depends on many factors, such as intensity, duration, and diurnal heat variation; genetic features of poultry; features of feeding and housing (floor or cellular housing) of poultry; poultry age and productivity; relative air humidity; design of poultry houses, etc. The timely forecast of heat stress onset and adequate measures for its prevention will help neutralize its negative effects on poultry and associated economic losses.

\section{REFERENCES}

1. Kadim L.T., A I - Q a m shui B.H.A., Mahgoub O., Ai-Marzooqi W., Johns o n E.H. Effect of seasonal temperatures and ascorbic acid supplementation on performance of broiler chickens maintained in closed and open-sided houses. Int. J. Poult. Sci., 2008, 7: 655-660 (doi: 10.3923/ijps.2008.655.660).

2. Abidin Z., K h a t o o n A. Heat stress in poultry and the beneficial effects of ascorbic acid (vitamin C) supplementation during periods of heat stress. World's Poult. Sci. J., 2013, 69: 135151 (doi: 10.1017/S0043933913000123).

3. Surai P.F., Fotin a T.I. Physiological mechanisms of stress development in poultry industry. Animal Breeding Today, 2013, 6: 54-60.

4. Te e te r R.G., S mith M.O., Owens F.N., Arp S.C., S angiah S., B reazdle J.E. Chronic heat stress and respiratory alkalosis: occurrence and treatment in broiler chickens. Poultry Science, 1985, 64: 1060-1064 (doi: 10.3382/ps.0641060).

5. Borges S.A., Fis cher Da Silva A.V., Majorka A., Hooge D.M., Cu m mings K.R. Physiological responses of broiler chicken to heat stress and electrolyte balance (sodium plus potassium minus chloride, milliequivalent per kilogram). Poult. Sci., 2004, 83: 1551-1558 (doi: $10.1093 / \mathrm{ps} / 83.9 .1551$ ).

6. Attia Y.A., H a s s a n R.A., Q ot a M.A. Recovery from adverse effects of heat stress on 
slow-growing chicks in the tropics 1: Effect of ascorbic acid and different levels of betaine. Tropical Animal Health and Production, 2009, 41: 807-818 (doi: 10.1007/s11250-008-9256-9).

7. Garriga C., Hunter R.R., A mat C., Planas J.M., Mitchell M.A., More to M. Heat stress increases apical glucose transport in the chicken jejunum. American Journal of Physiology-Regulatory, Integrative and Comparative Physiology, 2006, 290(1): 195-201 (doi: 10.1152/ajpregu.00393.2005).

8. Kavta ras hvili A.Sh. Ptitsevodstvo, 2012, 7: 13-17.

9. K a vt a r a s hili A.Sh. Zhivotnovodstvo Rossii, 2012, 9: 13-14.

10. Sahin K., Sahin N., Ku cuk O., H a y i rli A., Pras ad A.S. Role of dietary zinc in heat-stressed poultry: A review. Poult. Sci., 2009, 88(10): 2176-2183 (doi: 10.3382/ps.200800560).

11. Syafwan S., Kwakkelr P., Verstege n M.W.A. Heat stress and feeding strategies in meat-type chickens. World's Poult. Sci. J., 2011, 67: 653-673 (doi: 10.1017/S0043933911000742).

12. G o u s R.M., Mo r ris T.R. Nutritional interventions in alleviating the effects of high temperatures in broiler production. World's Poult. Sci. J., 2005, 61: 463-475 (doi: 10.1079/WPS200568).

13. D a g h i r N.J. Nutritional strategies to reduce heat stress in broilers and broiler breeders. Lohmann Information, 2009, 44: 6-15.

14. Huwaid a E.E. Malik, Rashid H.O. Suliaman, Ibrahim A. Yousif, Khalid M. E la mi n. Effect of dietary protein level and strain on carcass characteristics of heat stressed broiler chicks. Agric. Biol. J. N. Am., 2013, 4(5): 504-511 (doi: 10.5251/abjna.2013.4.5.504.511).

15. Te mi m S., Chagne a u A., Peresson M., Tesseraud S. Chronic heat exposure alters protein turnover of three different skeletal muscles in finishing broiler chickens fed 20 or $25 \%$ protein diets. $J$. Nutr., 2000, 130(4): 813-819.

16. T e e t e r R.G. Optimizing production of heat stressed broilers. Poultry Digest, 1994, 26: 10-24.

17. Che ng T.K., H a mbre M.X., C o o n C.N. Responses of broilers to dietary protein levels and amino acid supplementation to low protein diets at various environmental temperatures. $J$. Appl. Poultry Res., 1997, 6: 18-33.

18. Cheng T.K., Ham re M.X., C o on C.N. Effect of constant and cyclic environmental temperatures, dietary protein, and amino acid levels on broiler performance. J. Appl. Poultry Res., 1999, 8: 426-439 (doi: 10.1093/japr/8.4.426).

19. Z a man Q.U., Mushtaq T., Nawaz H., Mirza M.A., Mahmood S., Ahmad T., $\mathrm{B}$ ab a r M.E., Musht a q M.M.H. Effect of varying dietary energy and protein on broiler performance in hot climate. Animal Feed Science and Technology, 2008, 46: 302-312 (doi: 10.1016/j.anifeedsci.2008.01.006).

20. Ghazalah A.A., Abd-Els a me e M.O., Ali A.M. Influence of dietary energy and poultry fat on the response of broiler chicks to heat term. Int. J. Poult. Sci., 2008, 7(4): 355-359.

21. R e d B.L. Fat levels in layer feeds. Journal of the American Oil Chemists' Society, 1981, 58: 306-309.

22. Us a y a n N., F a r ra n M.T., A w ad alla h H.H.O., Al-Hawi I.R., As ma r R.J., A sh k a ri a n V.M. Effects of added dietary fat and phosphorus on the performance and egg quality of laying hens subjected to a constant high environmental temperature. Poult. Sci., 2001, 80: 1695-1701 (doi: 10.1093/ps/80.12.1695).

23. $\mathrm{N} \mathrm{jo} \mathrm{k} \mathrm{u} \mathrm{P.C.,} \mathrm{N}$ w a $\mathrm{z}$ o t a A.O.U. Effect of dietary inclusion of ascorbic acid and palm oil on the performance of laying hens in a hot tropical environment. Br. Poult. Sci., 1989, 30: 831-840 (doi: 10.1080/00071668908417209).

24. Musharaf N.A., Latshaw J.D. Heat increment as affected by protein and amino acid nutrition. World's Poult. Sci. J., 1999, 55: 233-240 (doi: 10.1079/WPS19990017).

25. D a g h i r N.J. Broiler feeding and management in hot climates. In: Poultry production in hot climates /N.J. Daghir (ed.). CABI, Oxfordshire, UK, 2008: 227-260.

26. D e B a silio V., Vilari no M., Y ahav S., P i c ard M. Early age thermal conditioning and a dual feeding program for male broilers challenged by heat stress. Poult. Sci., 2001, 80: 2936 (doi: 10.1093/ps/80.1.29).

27. E $\mathrm{m} \mathrm{m}$ a $\mathrm{n} \mathrm{s}$ G.C. Effective energy: a concept of energy utilization applied across species. $\mathrm{Br} . \quad J$. Nutr., 1994, 71: 801-821 (doi: 10.1079/BJN19940188).

28. Vjreck O., Ki r chgessne r M. Zum Erhaltungsbedarf on Energie und Rohprotein bei Legehenne. Arch. Teirernahr., 1980, 30(1): 10-12.

29. Kuznetsov N. Aminokislotnoe $i$ energeticheskoe pitanie myasnykh kur $v$ usloviyakh zharkogo klimata. Kandidatskaya dissertatsiya. Sergiev Posad, 1987.

30. M i le s D.M., B ra n t o n S.L., L o t t B.D. Atmospheric ammonia is detrimental to the performance of modern commercial broilers. Poult. Sci., 2004, 83: 1650-1654 (doi: $10.1093 / \mathrm{ps} / 83.10 .1650)$.

31. Yahav S. Ammonia affects performance and thermoregulation of male broiler chickens. Anim. Res., 2004, 53: 289-293 (doi: 10.1051/animres:2004015).

32. C ift c i M., E rt a s O.N., G u le r T. Effects of vitamin E and vitamin C dietary supplementation on egg production and egg quality of laying hens exposed to a chronic heat stress. Revue 
de Medecine Veterinaire, 2005, 156: 107-111.

33. Kavtarashvili A., Kolok ol'nikova T. Zhivotnovodstvo Rossii, 2010, 5-6: 17-20.

34. Sabah Elkheffi M.K., Mohammed Ahmed M.M., Abdel Gadir S.M. Effect of feed restriction and ascorbic acid supplementation on performance of broiler chicks reared under heat stress. Research Journal of Animal and Veterinary Sciences, 2008, 3: 1-8.

35. Mckee J.S., Harrison P.C., R is kowski G.L. Effects of supplemental ascorbic acid on the energy conversion of broiler chicks during heat stress and feed withdrawal. Poult. Sci., 1997, 76: 1278-1286 (doi: 10.1093/ps/76.9.1278).

36. Niu Z.Y., Y a n Q.L., Li W.C. Effects of different levels of vitamin E on growth performance and immune responses of broilers under heat stress. Poult. Sci., 2009, 88: 2101-2107 (doi: 10.3382/ps.2009-00220).

37. Rashidi A.A., Gofrani F., Ivari Y., Khatibjoo A., Vakili R. Effect of dietary fat, vitamin $\mathrm{E}$ and zinc on immune response and blood parameters of broilers reared under heat stress. Research Journal of Poultry Science, 2010, 3: 32-38 (doi: 10.3923/rjpscience.2010.32.38).

38. Asli M.M., Hos seini S.A., Lotfollahian H., Shariatmad a ri F. Effect of probiotics, yeast, vitamin $\mathrm{E}$ and vitamin $\mathrm{C}$ supplements on performance and immune response of laying hens during high environmental temperature. Int. J. Poult. Sci., 2007, 6: 895-900 (doi: 10.3923/ijps.2007.895.900).

39. Yardibi H., Turkay G. The effects of vitamin E on the antioxidant system, egg production, and egg quality in heat stressed laying hens. Turkish Journal of Veterinary and Animal Sciences, 2008, 32(5): 319-325.

40. F is in in V.I., S u r a i P., P a p a z y a n T. Ptitsevodstvo, 2009, 8: 10-14.

41. Li n H., W ang L.F., S ong J.L., X i e Y.M., Y ang Q.M. Effect of dietary supplemental levels of vitamin A on egg production and immune responses of heat-stressed laying hens. Poult. Sci., 2002, 81: 458-465 (doi: 10.1093/ps/81.4.458).

42. Whit e he ad C.C., Kelle r T. An update on ascorbic acid in poultry. World's Poult. Sci. J., 2003, 59: 161-184 (doi: 10.1079/WPS20030010).

43. S a hi n K., S a hi n N., S a ri M., Gurs u M.F. Effects of vitamins E and A supplementation on lipid peroxidation and concentration of some mineral in broilers reared under heat stress $\left(32{ }^{\circ} \mathrm{C}\right)$. Nutr. Res., 2002, 22: 723-731 (doi: 10.1016/S0271-5317(02)00376-7).

44. Ahmad T., S a rwar M., Mahr-Un-N is a, A h s a - U 1- H a q, Zia-U - - H a s a n. Influence of varying sources of dietary electrolytes on the performance of broilers reared in a high temperature environment. Animal Feed Science and Technology, 2005, 20: 277-298 (doi: 10.1016/j.anifeedsci.2005.02.028).

45. Mikhailovskaya O., Medvedenko A., S te pa n e nko V. Temperaturnyi stress $u$ kur nesushek $v$ zharkii period goda [Temperature stress in laying hens at hot season]. Hy-Line International, 2010 (http://www.hyline.com).

46. N e s h e i m M.C., Le a $\mathrm{ch}$ R.M., Z e i g le $\mathrm{r}$ T.R., S e r a f i n J.A. Interrelationships between dietary levels of sodium, chloride and potassium. J. Nutr., 1964, 84: 361-366.

47. A h m ad T., S a rwa r M. Dietary electrolyte balance: implications in heat stressed broilers. World's Poult. Sci. J., 2006, 62: 638-653 (doi: 10.1017/S0043933906001188).

48. B orges S.A., Fischer Da S ilva A.V., Maiorka A. Acid-base balance in broilers. World's Poult. Sci. J., 2007, 63(1): 73-81 (doi: 10.1017/S0043933907001286).

49. Kavtaras hvili A.Sh., Kolok o l' ni k ov a T.N. RatsVetInform, 2010, 4(104): 13-19.

50. B oulahsen A.A., Garlich J.D., Edens F.W. Calcium deficiency and food deprivation improve the response of chickens to acute heat stress. J. Nutr., 1993, 123: 98-105.

51. H i r a moto K., S a t o h K., Y a n o Y. Effect of diurnal fasting on broiler performance reared under summer condition. Japanese Poultry Science, 1995, 32: 169-176 (doi: 10.2141/jpsa.32.169).

52. Uzum M.H., O ral Toplu H.D. Effects of stocking density and feed restriction on performance, carcass, meat quality characteristics and some stress parameters in broilers under heat stress. Revue Méd. Vét., 2013, 164(12): 546-554.

53. Kavtarashvili A.Sh., Kolokol'nikova T.N. Feniks-Kus (Kazakhstan), 2010, 8: 11-18.

54. Kavt a ras hvili A.Sh. Ptitsa i ptitseprodukty, 2007, 5: 45-47.

55. L o t t B.D. The effect of feed intake on body temperature and water consumption of male broilers during heat exposure. Poult. Sci., 1991, 70: 756-759 (doi: 10.3382/ps.0700756).

56. Y a hav S., Hu rwitz S. Induction of thermotolerance in male broiler chickens by temperature conditioning at an early age. Poult. Sci., 1996, 75: 402-406 (doi: 10.3382/ps.0750402).

57. B a ln ave D., My he e re za S.K. Intermittent lighting and dietary sodium bicarbonate supplementation for laying hens at high temperatures. Australian Journal of Agricultural Research, 1998, 49: 279-284.

58. S ilva P.S., Sous a F.M., Fue nt as M.F. Influence of sodium bicarbonate on the performance of chickens reared under conditions of chronic high temperature in the period of 2142 days. Proc. $X X$ World's Poultry Congr. New Delhi, India, 1996: 256.

59. Zhang M., Wang D., Du R., Zhang W., Z hou S., Xie B. Effects of dietary chro- 
mium levels on performance and serum traits of broilers under heat stress. Acta Zoonutrimenta Sinica, 2002, 14: 5.

60. S a h i n K., S a h i n N., K u c u k O. Effects of chromium, and ascorbic acid supplementation on growth, carcass traits, serum metabolites, and antioxidant status of broiler chickens reared at a high ambient temperature (32 deg C). Nutrition Research, 2003, 23: 225-238 (doi: 10.1016/S0271-5317(02)00513-4).

61. Fis in in V.I., I mangulov Sh.A., Kavta rashvili A.Sh. Povyshenie effektivnosti yaichnogo ptitsevodstva [How to increase efficiency of commercial egg production in poultry]. Sergiev Posad, 1999: 143.

62. Li n H., Jia o H.C., Buyse J., De cuypere E. Strategies for preventing heat stress in poultry. World's Poult. Sci. J., 2006, 62: 71-86 (doi: 10.1079/WPS200585).

63. Kho a M.A. Wet and coarse diets in broiler nutrition: development of the GI tract and performance. Dissertation prepared in Wageningen Institute of Animal Sciences, Wageningen, 2007: 141.

64. La n P.T., S a k a mo to M., B e n n o Y. Effects of two probiotic Lactobacillus strains on jejunal and cecal microbiota of broiler chicken under acute heat stress condition as revealed by molecular analysis of 16S rRNA genes. Microbiol. Immunol., 2004, 48(12): 917-929 (doi: 10.1111/j.1348-0421.2004.tb03620.x).

65. S u ra i P., F ot i n a T. Efektivne ptakhivnitstvo (Ukraina), 2010, 8(68): 20-25.

66. M a r ki n Yu.V., S pi rido nov D.N., Z e vakova V.K., Polu n i a S.V. Kombikorma, 2011, 4: 59-60.

67. S u ra i P., F is i n i n V.I. Sel'skokhozyaistvennaya biologiya [Agricultural Biology], 2012, 4: 3-13 (doi: 10.15389/agrobiology.2012.4.3rus, 10.15389/agrobiology.2012.4.3eng).

68. D o nald J. Getting the most from evaporative cooling systems in tunnel ventilated broiler houses. World Poultry, 2000, 16: 34-39.

69. C z a ri c k M., T y s o n B.L. Design considerations for tunnel-ventilated broiler houses. $A S A E$ paper No. 89-4527. ASAE, St. Joseph, MI 49085-9659, 1989.

70. M a i 1 y a n E.S. Zooindustriya, 2007, 9: 8-13.

71. Kavt a r a h vili A.Sh. RatsVetInform, 2011, 7(119): 9-11.

72. Yahav S., Straschnow A., Luger D., Shinder D., Tanny J., Cohen S. Ventilation, sensible heat loss, broiler energy, and water balance under harsh environmental conditions. Poult. Sci., 2004, 83: 253-258 (doi: 10.1093/ps/83.2.253).

73. Kavtarashvili A.Sh., Kolokol'nikova T.N. Metody profilaktiki. Materialy Mezhdunarodnogo veterinarnogo kongressa «Aktual'nye veterinarnye problemy $v$ promyshlennom ptitsevodstve» [Proc. Int. Vet. Congress «Actual veterinary challenges in commercial poultry]. Moscow, 2013: 129-132.

74. Holi k V. Management of laying hens to minimize heat stress. Lohmann Information, 2009, 44(1): 16-29.

75. S a l a h H.M. Esmail. Thermal influences on poultry. World Poultry, 2001, 17(3): 26-27.

76. K a vt a r a s hili A. Ptitsevodstvo, 2013, 3: 17-25.

77. Gutie r rez W.M., M in W., C h a ng H.H. Effects of chilled drinking water on performance of laying hens during constant high ambient temperature. Asian Australasian Journal of Animal Sciences, 2009, 22(5): 694-699 (doi: 10.5713/ajas.2009.80549).

78. Piestun Y., Shinder D., Ruzal M., Halevy O., B rake J., Yahav S. Thermal manipulations during broiler embryogenesis: effect on the acquisition of thermotolerance. Poult. Sci., 2008, 87: 1516-1525 (doi: 10.3382/ps.2008-00030).

79. Yahav S., Mcmurthy J.P. Thermotolerance acquisition in broiler chickens by temperature conditioning early in life - The effect of timing and ambient temperature. Poult. Sci., 2001, 80: 1662-1666 (doi: 10.1093/ps/80.12.1662).

80. Yah av S., S a s s o $n$ R., S h ind e r D. The effect of thermal manipulations during embryogenesis of broiler chicks (Gallus domesticus) on hatchability, body weight and thermoregulation after hatch. J. Therm. Biol., 2004, 29: 245-250 (doi: 10.1016/j.jtherbio.2004.03.002).

81. Tzschentke B., Plage man n A. Imprinting and critical periods in early development. World's Poult. Sci. J., 2006, 62: 626-637 (doi: 10.1017/S0043933906001176).

82. T z s c h e n t k e B. Attainment of thermoregulation as affected by environmental factors. Poult. Sci., 2007, 86: 1025-1036 (doi: 10.1093/ps/86.5.1025).

83. Miftakhutdinov A.V. Uchenye zapiski UO Vitebskaya ordena «Znak Pocheta» gosudarstvennaya akademiya veterinarnoi meditsiny, 2011, 47(2/1): 188-190.

84. E 1-Gendy E., Was h bu rg K.W. Genetic variation in body temperature and its response to short-term acute heat stress in broilers. Poult. Sci., 1995, 74: 225-230 (doi: 10.3382/ps.0740225).

85. Gowe R.S., F a i rfull R.W. Breeding for resistance to heat stress. In: Poultry production in hot climates /N.J. Daghir (ed.). CABI, Oxfordshire, UK, 2008: 13-30.

86. D e e b N., C a ha ner A. Genotype by environment interaction with broiler genotypes differing in growth rate. 3. Growth rate and water consumption of broiler progeny from weightselected versus non selected parents under normal and high ambient temperatures. Poult. Sci., 
2002, 81: 293-330.

87. Franco-Jimenez D.J., Scheideler S.E., Kittok R.J., Brown-Brandl T.M., R o b e s o n L.R., T a i r a H., B e ck V.V. Differential effects of heat stress in there strains of laying hens. J. Appl. Poultry Res., 2007, 16(4): 628-634 (doi: 10.3382/japr.2005-00088).

88. Melesse A., Maak S., Pingel H., Lengerken G.V. Assessing the thermotolerance potentials of five commercial layer chicken genotypes under long-term heat stress environment as measured by their performance traits. J. Anim. Prod. Adv., 2013, 3(8): 254-264 (doi: 10.5455/japa.20120929125835).

89. De e b N., C a h a ne r A. Genotype-by-temperature interaction with broiler genotypes differing in growth rate. 1. The effects of high ambient temperature and naked-neck genotype on lines differing in genetic background. Poult. Sci., 2001, 80: 695-702.

90. Raju M.V., Sunder G.S., Chawak M.M., Rao S.V., S ad ag o p a n V.R. Response of naked neck (Nana) and normal (nana) broiler chickens to dietary energy levels in a subtropical climate. Br. Poult. Sci., 2004, 45: 186-193 (doi: 10.1080/00071660410001715786).

91. M e rat P. Potential usefulness of the Na (naked neck) gene in poultry production. World's Poult. Sci. J., 1986, 42: 124-142 (doi: 10.1079/WPS19860010).

92. Yun is R., C a h a ne r A. The effects of the naked neck $(\mathrm{Na})$ and frizzle $(F)$ genes on growth and meat yield of broilers and their interactions with ambient temperatures and potential growth rate. Poult. Sci., 1999, 78: 1347-1352 (doi: 10.1093/ps/78.10.1347). 